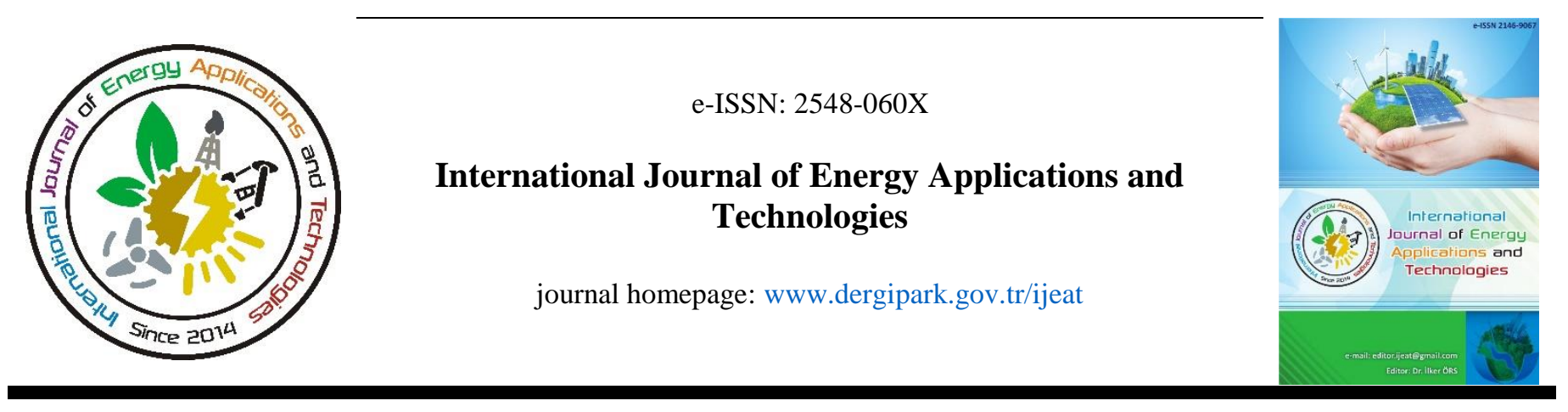

Original Research Article

\title{
A Turkish CHP case study; techno-economic, environmental and policy analysis
}

\author{
Awais Ahmad ${ }^{1}$, Alvaro Diez ${ }^{2 *}$ \\ ${ }^{I}$ Department of Energy Systems Engineering, Izmir Institute of Technology, Izmir, Turkey \\ ${ }^{2}$ Department of Mechanical Engineering, Izmir Institute of Technology, Izmir, Turkey
}

ARTICLE INFO
* Corresponding author
alvarodiez@ iyte.edu.tr
Received August 21, 2018
Accepted September 11, 2019
Published by Editorial Board
Members of IJEAT
C This article is distributed by
Turk Journal Park System under
the CC 4.0 terms and conditions.
doi: $10.31593 /$ ijeat.454799

\begin{abstract}
The Turkish energy policy requires a strategic framework for sustainable economic growth, energy security and to meet the continuously rising energy demand. The 2030 energy plan of Turkey has a target to achieve $30 \%$ of its electricity generation from renewable technology with a significant reduction in global Green House Gas emissions by utilizing local renewable energy resources and clean technologies. Also, the Turkish energy network requires a significant contribution from other technologies such as combined heat and power and integrated energy systems to develop a strong, efficient and effective renewable energy network.

This case study involves a techno-economic, policy and environmental assessment of a combined heat and power system for the Izmir Institute of Technology. It highlights the inefficiency of the existing system and proposes a CHP system to meet the current and future energy requirement. Two systems were taken into consideration, a gas turbine and a reciprocating engine based combined cycle systems to analyze the best possible scenario to achieve sustainability.

The result shows that the reciprocating engine based system provided a reduction of $77 \%$ of $\mathrm{CO}_{2}$ emissions with increased overall efficiency of $47 \%$ and 0.166 million USD annual savings in comparison with the grid-based system and gas turbine with a reduction of $8 \%$ of $\mathrm{CO}_{2}$ emissions and increased overall efficiency of $43.5 \%$. The outcome depict the importance of the CHP system on universities, institutes, and residential applications and emphasize on the modification of the policies towards the 5th generation energy network, including a combination of different technologies to achieve the energy and environmental targets for strengthening the Turkish energy network.
\end{abstract}

Keywords: Energy efficiency; Combined heat and power; Energy policy; Techno-Economic environmental analysis; Sustainability

\section{Introduction}

One of the most important aspects of our life is energy. It has played an important role in the transformation of our society. From the last decade, energy consumption has increased in such a way that it has become the backbone of every country and now it directly determines the gross domestic product (GDP) of a country. The use of energy resources is not restricted to only one field; several sectors like transportation, industrial, commercial, agricultural and residential sector are among the most significant consumers. However, there are still more than two billion people deprived of this basic form of energy. In the future, energy demand is expected to increase and energy-efficient technologies coupled with renewable energy will be required to achieve the sustainability goals and to ensure that this basic necessity is available for everyone. 
Moreover, fossil fuels have a major share for providing the world's energy demand; as a result, these reserves have been drastically reduced. This depletion is highly favored by inefficient generation technologies, poor transmission and distribution systems. Besides, these inefficiencies are causing harmful emissions that are leading to environmental pollution. The effects associated with fossil fuels are extremely harmful including mainly air pollution, ozone depletion and disastrous effects to land, property, aquatic life and human beings. As discussed, fossil fuel provides $80 \%$ of the primary energy and is responsible for $90 \%$ of the energyrelated emissions. Today, the total energy-related $\mathrm{CO}_{2}$ emissions amount to nearly $39 \mathrm{Gt} \mathrm{CO}_{2}$-equivalent. Threequarters of these emissions are accounted for only eight sources. The largest source is coal-fired power plants, producing $27 \%$ of the emissions. Buildings make up nearly $9 \%$, followed by gas-fired power generation systems and petroleum cars making $8 \%$ of the total emissions. Cement, oil and gas operations account for $7 \%$ of the total emissions, with trucks making up 6\% and steel around 5\% [1].

Due to global climate change, resource scarcity and energy security, the international community is investing in renewable and sustainable technologies to produce less vulnerable effects for the environment. These concerns can only be eliminated by implementing strategic energy plans. One of them is to exploit a never-ending source of renewable energy, while the other is the development of a sustainable and efficient energy system. If the precautionary measures were to be taken by the society and organizations, the global carbon intensity would decrease from $39 \mathrm{Gt} \mathrm{CO}_{2}$-equivalent (2019) to $21 \mathrm{Gt} \mathrm{CO}_{2}$-equivalent in 2040 [1]. The key to achieving this target is to invest in sustainable technologies and systems' improvements. In 2018, the total amount of energy production from the renewable source was estimated to be $5886 \mathrm{TWh}$. However, these technologies are with lower returns and high cost of production per kilowatt-hour, which is a crucial barrier towards its development. Until now, conventional and non-conventional fossil fuel sources remain prominent for energy production.

Cogeneration/Trigeneration is a widely used technology that generates heat, cooling, and power from the same fuel source. These systems can be integrated with other renewable and conventional systems, making them more effective, allowing to increase efficiency while reducing emissions. Under modern energy infrastructure, the combined heat and power (CHP) is considered as an important part of the fourth generation heating and cooling networks as benefits of the combined heat and power in terms of sustainability, pollution and profitability are far greater and it is considered as a bridge towards sustainable and renewable future.

Several case studies have been performed, emphasizing the importance of combined heat and power in different sectors.
Among them is the study was done for the exergy, economic and environmental analysis of the novel cogeneration system and it was observed that the average cost of produced power and steam reduced by $0.56 \$ / G J$ [2]. The study carried out by Gopalakrishnan \& Kosanovic to optimize the combined cycle district heating system depending upon the weather conditions [3]. Another study carried out by Mondol and Carr analyzed the conventional and advanced combined cycle gas turbine (CCGT) systems for discussing UAE energy transition, future opportunities, and challenges [4]. Balli and his colleagues also carried out a performance assessment study for the CHP system in Eskisehir city of Turkey [5]. Celador with his colleagues studied small scale CHP systems for residential applications in Spain and discussed their techno-economic feasibility [6]. Moreover, Nemati and his colleagues analyzed the benefits and problems of ORC and Kalina cycle based CHP systems through thermodynamic modeling [7]. Giarola and her colleagues developed case studies for the CHP with fuel cell using biogas as a fuel source with cost and emission analysis and the results suggested a decrease in capital and fixed operating cost and a significant reduction in emissions [8]. Karlsson, Brunzell, and Venkatesh studied the life cycle assessment of fuels to be used in waste to combined heat and power and suggested wood waste to be the best alternative regarding greenhouse emissions [9]. Havukainen and his colleagues studied a small scale CHP system with forest biomass as fuel and found out that global climate impacts are reduced as compared to natural gas [10]. Szega and Żymełka worked on the thermodynamic and economic assessment of a CHP system with a steam-powered absorption chiller for Trigeneration and Cogeneration applications with an estimated payback period of 13 years [11]. Keynia studied on supplying residential buildings the heating, cooling, and electricity with generation and cogeneration and optimized the conditions using algorithms and found out that the operation is feasible with annual revenue of $\$ 93,251$ and return rate period of 5 years [12]. Tataraki and his colleagues studied the combined heat and power systems with a conventional system like boilers, chillers and reversible heat pumps on the basis of economic analysis to give policymakers or investors an important insight for decision making [13].

In this paper, a techno-economic analysis of two unique decentralized CHP systems based on gas turbine and the reciprocating engine is made to provide the most sustainable and economical configuration for the Izmir Institute of Technology, Turkey. Moreover, it will include an overview of CHP policies, its growth in Turkey and the rest of the world is discussed. It also explains the environmental and sustainability aspects of the CHP system and its importance towards national security and energy efficiency. It supports the idea of implementing these technologies and their 
integration in the modern energy network on institutional, universities, large residential and commercial complexes.

\section{Policy and Framework}

Most of the European countries have a very specific and clear policy about CHP. Most have their framework according to the saving potential, infrastructure, financial resources and their plan for the future energy network. The EU directive 2018/2002 is focused on energy efficiency and utilization of combined heat and power systems coupled with the district heating system. The main purpose of this directive is to establish and implement a proper framework for a resilient energy union with a focus on climate change policy, improving energy efficiency, improving air quality and public health, reduce greenhouse gases and improving energy security in the member states. The European Parliament urged the member states to involve CHP in their national energy efficiency plans [14]. Meanwhile, the conference in Brussels ended with the consensus to develop and expand the CHP markets by implementing policies in the member state by 2020 , it was also recognized that there is still $120 \mathrm{GWe}$ that can be exploited by CHP in the EU countries [15]. For example, in Spain, the framework of CHP is known by Royal Decree 661/2007. It involves the promotion of both renewable energy and CHP. Through this, it has been estimated that only in residential applications there is a potential of $9703 \mathrm{MW}$ that could be exploited by highly efficient cogeneration [6]. Germany is considered the leading country for its commitment to climate protection, energy efficiency and alternative energy. The German Integrated Energy and Climate Strategy constitute of 14 laws and ordinances being implemented in two stages and CHP is the key element for electricity and heating. Germany was awarded the COGEN European Recognition Award in 2009, which shows how CHP is playing an important role in the German economy. Under CHP Law 2012, Germany is to increase the share of cogeneration to $25 \%$ by 2020 . It has the biggest CHP market in Europe and the implementation of new policies are continuously increasing the investment in the combined heat and power system [16]. The Managing Director of COGEN Europe stated that by 2050 the total world annual saving could reach up to 500 billion Euros, equivalent to $57 \%$ energy reduction in demand. In industry, the savings could reach to 9 Mtoe (Million tons of oil equivalents), while improving district heating and CHP could lead to savings to an amount of 10 Mtoe and technical savings could reach to 95 Mtoe by 2050 .

The case for Turkey is a bit more complex when compared to the EU. The reason lies in extensive negligence in the monitoring and management of energy resource, consumption and record keeping. Energy-saving potential in Turkey is humongous as Turkey's energy sector is huge with extensive utilization in industrial, commercial and residential applications. It is the 11th biggest iron and steel producer in the world with an estimated energy saving potential of $60 \mathrm{PJ}$ per year only from this sector. In cement production, the energy-saving potential is estimated to be $46 \mathrm{PJ}$ per year. Overall, the saving potential in the manufacturing, glass and textile industry is $36 \%, 16 \%$ and $35 \%$ respectively. When it comes to the residential sector, the heating consumption is $75 \%$ of the total energy consumption in Turkey and $75-80 \%$ of which comes from natural resources like natural gas. It has been assessed that the saving potential of this sector is about $30-50 \%$, but it could be up to $80 \%$ [17]. Also, Turkey consumes a high amount of heat per unit area in residential buildings as compared to European countries e.g. In Denmark the heating consumption per unit area is 23 $\mathrm{kWh} / \mathrm{m}^{2}$.year, for Netherland it is $34 \mathrm{kWh} / \mathrm{m}^{2}$.year, for the $\mathrm{UK}$ it is $35 \mathrm{kWh} / \mathrm{m}^{2}$.year and $100 \mathrm{kWh} / \mathrm{m}^{2}$.year in case of Turkey [18]. The reason for this drastic difference is due to the better integration of systems, energy-efficient technologies, zero-energy designs, intelligently integrated network and well-monitored implementation of policies. Some of the practical examples include commercialization and expansion of decentralized combined heat and power system on large, medium and small scales through policy reforms, feed tariff schemes and other incentives like in the UK, utilization of smart grids from different conventional and renewable energy sources with intelligent monitoring and forecasting of energy demand and supply in Denmark e.g. Bornholm Island is a great illustration of an intelligent smart grid network. Moreover, the net-zero energy building concept integrated with district heating and cooling systems is widely implemented for improving energy efficiency like the development of Solallén, a multi-housing facility in 2017 made by a Skanska a renowned Swedish construction company and Vikki, an office building located in Helsinki is based on net-zero design and consumes $50 \%$ less energy than the national building code standard [19].

The benefits of combined heat and power have forced countries to invest in technologies like combined heat and power, hybrid systems whose integrated efficiency can reach up to $85-90 \%$ depending upon the system integration, generating less pollution and reducing losses. However, in Turkey there is no remarkable policy change is expected in the near future [20].

In Turkey, the National Energy Efficiency Action Plan 20172023, focuses on the enforcement of combined heat and power in all sectors for improving energy security and energy efficiency. However, little improvements have been made since. The capacity of combined heat and power reached $5000 \mathrm{MW}$ in 2009 , but it has not increased as expected, perhaps due to the increasing natural gas prices in the country and lack of policies favoring CHP. 
The recent short term policy, which was introduced in Turkey by the Ministry of Development in July 2013 focuses on all these aspects [21]. Article 794 focuses on the energy efficiency strategy to be applied in all sectors. Under Article 789, the network and resources of oil and gas must be increased with the help of transmission and distribution systems [22]. A serious strategic and concise framework that defines the implementation of combined heat and power in each sector with subsidies to motivate investors is needed in Turkey.

Even though the energy efficiency law states that technologies must be used to increase energy efficiency, but a concise planning and framework is extremely essential to define the goals, paths, and source in order to achieve the energy and environmental targets.

\section{Methodology}

\subsection{Thermal and electrical data}

The capacity depends on the procedure of the data collection and interpretation to make certain extrapolations as accurate as possible to estimate the exact demand. The electricity data for the Izmir Institute of Technology (IYTE) was obtained from the administrative authorities of the Institute. Detailed data were available for the years 2013, 2014 and 2015 on the consumption of each department and building without the last four months of 2015's data, which were estimated by considering the trend in 2013 and 2014 during the same months. The extrapolation of data until 2023 had to take into account the addition of new department buildings (as part of the expansion plans) and the annual percentage increase. For the increase due to the addition of new departmental buildings, an average of the existing buildings was evaluated to analyze the consumption that each new department would add, see Table 1.

Based on the expansion plan, the increase in demand was estimated according to the average consumption as shown in Table 2.

The annual percentage increase was based on the last year's difference. After 2019, the annual percentage increase was assumed to decline linearly, until it will reach a stable value in 2023, considering energy efficiency measures and no new building addition leading to a steady or reduced electricity consumption, as shown in Table 3.

The heating and cooling extrapolation was based on the average percentage of 2013, 2014 and 2015. October was assumed to be the month when no heating or cooling was required due to mild weather conditions, see Figure 2 for historical maximum and minimum average temperature values for the region of Izmir.

Thus, October's electricity consumption was taken as a reference to discern between heating, cooling, and normal electricity consumption. The total percentage of cooling and heating in 2013 was $59.2 \%$ and $40.8 \%$. In 2014, the share of heating and cooling was increased by $4.1 \%$ to $62.8 \%$ for cooling and $37.1 \%$ for heating. During 2015, percentage share for cooling decreased to $58.5 \%$ and for heating $42.1 \%$. These three years provide a basis for extrapolation of heating and cooling by taking the average percentage for these 3 years. Average consumption for cooling $60 \%$ and heating $40 \%$ is used to evaluate consumption on an annual basis, considering these percentages will remain constant as neglecting small changes. Table 4 shows the extrapolated value based on the average percentage after 2015 .

Table 1. Average building consumption, KWh

\begin{tabular}{cc}
$\begin{array}{c}\text { 2015 Average } \\
\text { Consumption KWh }\end{array}$ & Buildings \\
\hline 551170 & Science Faculty (4 Departments) \\
474950 & Engineering Faculty (5 Departments) \\
376426 & Mechanical Engineering \\
376402 & Architecture (4 Blocks) \\
757632 & Chemical Engineering \\
418867 & Administration Building \\
\hline
\end{tabular}

Table 2. Consumption addition due to expansion plan 2023

\begin{tabular}{ccc}
\hline Year & $\begin{array}{c}\text { Consumption with Building } \\
\text { Addition, KWh }\end{array}$ & Buildings \\
\hline 2016 & 985149 & 2 \\
2017 & 985149 & 2 \\
2018 & 492574 & 1 \\
2019 & 492574 & 1 \\
2020 & 0 & 0 \\
2021 & 0 & 0 \\
2022 & 0 & 0 \\
2023 & 0 & 0 \\
\hline
\end{tabular}

Table 3. Total Consumption until 2023

\begin{tabular}{cccc}
\hline Year & $\begin{array}{c}\text { Consumption } \\
\text { due to Building } \\
\text { Addition, KWh }\end{array}$ & $\begin{array}{c}\text { Annual } \\
\text { Consumption } \\
\text { Increase, KWh }\end{array}$ & $\begin{array}{c}\text { Total } \\
\text { Consumption, } \\
\text { KWh }\end{array}$ \\
\hline 2013 & 0 & 170725 & 4955615 \\
2014 & 0 & 10339 & 4965954 \\
2015 & 0 & 160495 & 5126449 \\
2016 & 985149 & 165682 & 6277280 \\
2017 & 985149 & 204011 & 7466441 \\
2018 & 492574 & 261325 & 8220341 \\
2019 & 492574 & 250720 & 8963636 \\
2020 & 0 & 279665 & 9243301 \\
2021 & 0 & 269805 & 9733335 \\
2022 & 0 & 243333 & 9976668 \\
2023 & 0 & 159626 & 10136295 \\
\hline
\end{tabular}

For estimating the final capacity in $\mathrm{kWh}$, the normal operating hours of the institute is taken 9 to 5 , which suggests. The normal 8 working hours with 5 days a week gives the utility consumption for the working days but to incorporate the consumption during the weekend and the consumption after working hours, the other 2 remaining days (weekends) gives the value of the fluctuations for better approximation. 


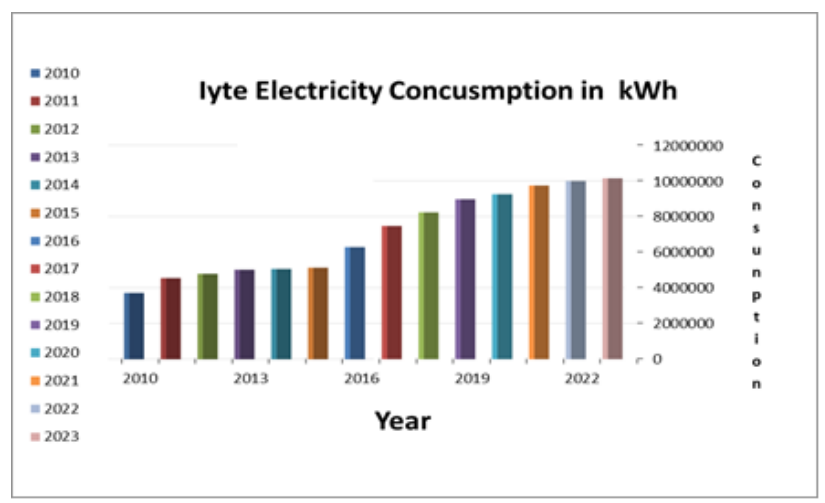

Fig. 1. IYTE electricity consumption until 2023

Table 4. Electricity, heating and cooling consumption until 2023

\begin{tabular}{ccccc}
\hline Year & $\begin{array}{c}\text { Electricity, } \\
\text { KWh }\end{array}$ & $\begin{array}{c}\text { Heating, } \\
\text { KWh }\end{array}$ & $\begin{array}{c}\text { Cooling, } \\
\text { KWh }\end{array}$ & Total, KWh \\
\hline 2013 & 2743782.0 & 894996.8 & 1316836.1 & 4955615.0 \\
2014 & 2749506.4 & 896864.0 & 1319583.4 & 4965954.0 \\
2015 & 2838367.9 & 925849.8 & 1362231.1 & 5126449.0 \\
2016 & 3475550.2 & 1133692.9 & 1668037.0 & 6277280.2 \\
2017 & 4133954.5 & 1348458.4 & 1984028.1 & 7466441.1 \\
2018 & 4551367.3 & 1484614.7 & 2184359.0 & 8220341.2 \\
2019 & 4962908.5 & 1618855.7 & 2381871.9 & 8963636.2 \\
2020 & 5117751.3 & 1669364.0 & 2456186.3 & 9243301.7 \\
2021 & 5389068.7 & 1757865.3 & 2586401.0 & 9733335.1 \\
2022 & 5523795.5 & 1801812.0 & 2651061.0 & 9976668.5 \\
2023 & 5612176.2 & 1830640.9 & 2693478.0 & 10136295.2 \\
\hline
\end{tabular}

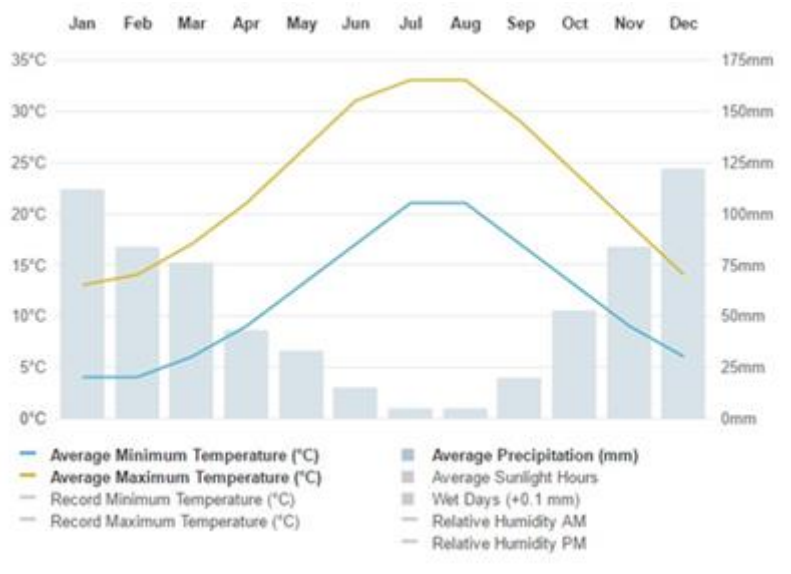

Fig. 2. Average maximum and minimum temperature for Izmir (BBC, 2016)

It was assumed that during the following 5 to 7 years, the consumption would most likely remain stagnant after 2023 as represented in Figure 1. This total capacity of combined cycle plant was based on electrical and cooling consumption, as heat and cooling do not occur at the same time, for this reason the heat produced can be passed before the steam turbine to meet the heating requirement. The total capacity evaluated to be $2.9 \mathrm{MW}$.

\subsection{Energy calculation and design}

After selecting the capacity of the power plant, the prime mover was chosen on the basis of the heat to power ratio.
Each part of a CHP system has an effect on the overall efficiency. As the prime mover, the heat recovery system's inlet and outlet conditions affect the electrical output of the system. During designing of the system, the choice of prime mover and the parameters to operate the plant is the key for achieving high efficiency.

The prime movers selection is based on parameters like efficiency, maximum waste heat utilization, multiple fuel firing, and better control and monitoring. The gas turbine selected is from Solar Turbine, a Centaurs 40 with a capacity of 3.5 WM [24] with a power output slight higher than IYTE's requirement and the excess electricity will be sold to the grid or other consumers. For the reciprocating engine, 2 types 4 JSM 420 engines are selected with an individual power output of 1.415 MW [25]. The flow rates are obtained from the manufacturer's data sheet [26]. For the fuel's properties, the composition and lower heating value of natural gas of $35 \mathrm{MJ} / \mathrm{Nm}^{3}$ were taken from Duzen's natural gas analysis for Turkey [27]. For the combustion analysis, first stoichiometric calculations were done to find the theoretical amount of air to fuel ratio and these were compared with actual calculations based on the mass ow rates. The combustion analysis is based on previous studies $[28,29]$.

The next part was to evaluate the heat recovery steam generation system to produce high-quality steam for the steam turbine. The heat recovery steam generation system having three sections, known as economizer, evaporator, and super heater. A single pressure HRSG was used for this study as seen in Figure 3. The methodology for the HRSG heat calculations was based on Ganapathy waste heat boilers guide [27]. For the waste heat recovery calculations, the following assumptions were taken from [30]:

- The inlet temperature of feed water.

- Blowdown to be negligible.

- Pinch point and Approach point assumption.

- Steam turbine inlet pressure to be same as the superheater pressure.

- Considering no pressure drop and minimal the temperature drop from superheater and steam turbine.

- Steady-state conditions.

- Unfired HRSG

- A pressure drop between evaporator the superheater is considered.

The calculations were based on a single pressure heat recovery steam generator. The calculation of the exit stack temperature and the exit mass flow rate of steam, required for the steam turbine to work at designated temperature and pressure, were evaluated using an energy balance on the evaporator, superheat and then economizer. The nominal operating conditions were evaluated using iterative analysis 
based on the industrial waste heat recovery calculations [31]. The heat balance follows the following equations were as follows:

Economizer; $m_{g t} C p_{g}\left(\operatorname{tg}_{3}-\operatorname{tg}_{4}\right)=m_{s t}\left(h_{\text {app }}-h_{f w}\right)$
Evaporator; $m_{g t} C p_{g}\left(\operatorname{tg}_{2}-\operatorname{tg}_{3}\right)=m_{s t}\left(h_{s 2}-h_{\text {app }}\right)$
Superheater; $m_{g t} C p_{g}\left(\operatorname{tg}_{1}-\operatorname{tg}_{2}\right)=m_{s t}\left(h_{s h}-h_{s 2}\right)$

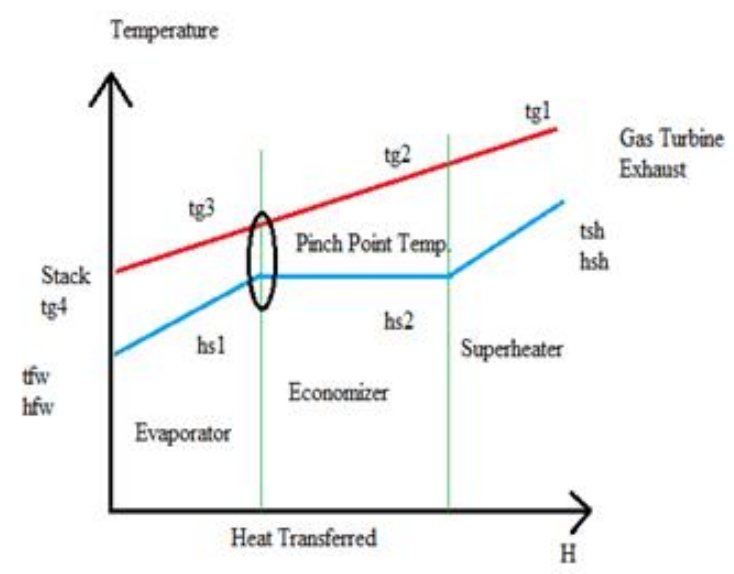

Fig. 3. Single Pressure HRSG T-H diagram

Table 5. Energy analysis for the gas turbine and reciprocating engine

\begin{tabular}{lcc}
\hline \multicolumn{1}{c}{ Parameters } & Gas Turbine & $\begin{array}{c}\text { Reciprocating } \\
\text { Engine (2 Engine's) }\end{array}$ \\
\hline Mass of fuel, kg/s & 0.540 & 0.065 \\
Mass of air, kg/s & 18.4 & 4.12 \\
$\mathrm{~W}_{\text {net }}$, Prime Mover, MW & 3.50 & 2.83 \\
Excess air, \% & 185.3 & 168.2 \\
Efficiency of Prime Mover, $\%$ & 28.3 & 44 \\
Steam generation rate, $\mathrm{kg} / \mathrm{h}$ & 8273.0 & 1163.0 \\
Exhaust temperature, ${ }^{\circ} \mathrm{C}$ & 194.6 & 212.0 \\
Efficiency of HRSG & 38.2 & 28.0 \\
Steam turbine output, MW & 1.836 & 0.27 \\
Steam turbine efficiency, \% & 46 & 42.5 \\
Pump Work, kW & 9.04 & 0.545 \\
Total electrical efficiency of & 75 & 86 \\
CCP,\% & & 47.0 \\
Fuel based efficiency of & 43.5 & \\
CCP, \% & & \\
\hline
\end{tabular}

The steam turbine was selected before the HRSG calculations as the steam turbine inlet pressure was used as a basis for the superheater pressure and temperature assumptions. The basis of steam turbine selection was the energy required, steam turbine efficiency, operation in condensing or backpressure mode for increased efficiency and energy requirement. For the gas turbine case, a $700 \mathrm{~kW}-3$ MW capacity PBS Energy condensing steam turbine [32] was selected since it has higher efficiency than a conventional multi-stage turbine and it has the ability to work on both fully condensing/fully backpressure mode. While for reciprocating engine case, due to less exhaust ow rate, the steam turbine is a $75 \mathrm{~kW}-300 \mathrm{~kW}$ in capacity from Siemens, used for small scale combined heat and power applications [33]. The results of the energy calculations are shown in Table 5.

\subsection{Emission analysis}

The cases were divided into three sections, first the gas turbine, second the reciprocating engine and third the emissions from grid electricity. After analyzing each case, a comparison of emissions between existing and proposed the system was made to highlight the optimal solution in term of environmental pollution reduction.

There are generally two ways for calculating emissions, one is by continuous monitoring of the emission source, while the other is by using emissions factors. The evaluation of the emissions factors is strictly dependent on the countryspecific emission factor. Emissions factors vary based on production, consumption, and generation of electricity with its specific emissions rate. For the proposed systems, namely the gas turbine and the reciprocating engine CHP, the emissions factors for the gas turbine and reciprocating engine were taken as the stationary combustion emissions factors from the Environmental Protection Agency. The emissions factors given were for a $38 \mathrm{MJ} / \mathrm{Nm}^{3}$ calorific value; therefore, a reduced value was taken for the given calorific value of 35 $\mathrm{MJ} / \mathrm{Nm}^{3}$ according to the percentage change in the calorific values [34]. The emissions were represented in $\mathrm{CO}_{2}$ equivalent units, the Global Warming Potential (GWP) the index was used for conversion of other pollutants into $\mathrm{CO}_{2}$ equivalent.

Table 6. Emissions analysis

\begin{tabular}{ccccc}
\hline Parameters & & $\begin{array}{c}\text { Gas } \\
\text { Turbine }\end{array}$ & $\begin{array}{c}\text { Reciprocating } \\
\text { Engine }\end{array}$ & $\begin{array}{c}\text { Grid Based } \\
\text { Emissions }\end{array}$ \\
\hline $\begin{array}{c}\text { Total Energy } \\
\text { Consumed, }\end{array}$ & ---- & 64713 & 15779232 & 10136295 \\
kWh/year. & & 600 & & \\
Emission & $\mathrm{CO}_{2}$ & 0.166 & $1.66 \times 10^{-1}$ & 1.009 \\
Factor & $\mathrm{CH}_{4}$ & $3.14 \times 10^{-6}$ & $3.14 \times 10^{-6}$ & $1.30 \times 10^{-5}$ \\
& $\mathrm{~N}_{2} \mathrm{O}$ & $3.14 \times 10^{-7}$ & $3.14 \times 10^{-7}$ & $1.20 \times 10^{-5}$ \\
$\begin{array}{c}\text { Emissions, } \\
\text { ton } \mathrm{CO}_{2 \mathrm{eq}} / \mathrm{year} \\
\text { T\&D }\end{array}$ & ---- & 10802.3 & 2633.9 & 10275.1 \\
$\begin{array}{c}\text { Emission } \\
\text { Factor }\end{array}$ & $\mathrm{CO}_{2}$ & ---- & ---- & \\
& $\mathrm{CH}_{4}$ & ---- & ---- & $1.85 \times 10^{-6}$ \\
$\begin{array}{c}\text { T\&D related } \\
\text { Emissions, } \\
\text { ton } \mathrm{CO}_{2 \mathrm{eq}}\end{array}$ & ----- & ---- & ---- & $1.65 \times 10^{-6}$ \\
Total & & & & 1475.2 \\
$\begin{array}{c}\text { Emissions, } \\
\text { ton } \mathrm{CO}_{2 \mathrm{eq}} \mathrm{O}\end{array}$ & ---- & 10802 & 2634 & 11750 \\
\hline
\end{tabular}

For grid-based emissions, the emissions factors are different from USEPA stationary combustion [35]. Each country has its own specific emissions factors, which vary depending on the industry, fuel, and type of technology being used for grid emissions. As grid includes electricity from different technologies thus using stationary combustion emissions factors would be inappropriate. The grid-based emissions 
factors given by the DEFRA are represented in the 2012 guidelines for calculation of emissions for the United Kingdom only. IEA also provides a grid-based emissions factors but those are for electricity, heating, and cooling. As in this study, the heating and cooling system was based on electricity, using the IEA emissions factors would have led to a divergence in the result. Therefore, the approach taken in this study was by using electricity specific emissions factors for grid emissions given by Brander [36]. The emissions from the grid also include the emissions associated with transmission and distribution (T\&D) losses found by using specific emissions factors for $T \& D$ losses. The emission analysis is shown in Table 6.

\subsection{Economic analysis}

The cost estimation was also divided into three cases. The CHP based on the gas turbine, CHP based on the reciprocating engine and the third was the cost analysis of the grid-based facility. The CHP cases were further divided into two sub-cases based on the operating hours: 2880 hour per year and 8000 hours per year to estimate what mode of operation would provide a more optimal outcome. For the grid base cost estimation, the cost was divided into 4 subsections.

1. Grid Electricity purchase cost

2. Maintenance cost

3. Transmission and distribution loss cost

4. Fuel for generator and heating system.

The cost of electricity for this study was 0.067 USD per kWh as the actual price paid by the institute in 2015. A report published by the Garanti Bank showed an increase in the baseload price of electricity on an hourly basis until 2022 [39]. This report was used to estimate the electricity price increase until 2023.

Table 7. Cost estimation for grid based (existing) systems

\begin{tabular}{cc}
\hline Parameters & Cost Million USD/ Year \\
\hline Maintenance Cost & 0.08 \\
T\&D Cost & 0.06 \\
Fuel Cost & 0.32 \\
Annual Electricity Cost 2016 & 0.343 \\
Total Cost & 0.81 \\
\hline
\end{tabular}

The electricity transmission and distribution losses account for the fuel loss due to transmission between the source of supply and point of distribution. The World Bank maintains the record of how much each country loses in terms of transmission and distribution. It found that the losses have been increased in the last three years from $14.1 \%$ to $15.5 \%$ with an average of $0.675 \%$ per year [40]. If no measures are taken in this matter, then this trend for transmission and distribution loss provides a $17.5 \%$ loss in 2016 and $22.2 \%$ loss in 2023. The operation and maintenance cost was based on a report by Cuttica and Haefke [37]. Further analysis of several plants depicts that the O\&M cost ranges from 0.005-
0.008 USD per $\mathrm{kWh}$ for the gas turbine and $0.010-0.015$ USD per $\mathrm{kWh}$ for the reciprocating engines [38]. Table 7 shows the cost analysis for the existing system.

Table 8. Cost Calculation for CHP Cases

\begin{tabular}{ccccc}
\hline Parameters & \multicolumn{2}{c}{ Gas Turbine } & \multicolumn{2}{c}{$\begin{array}{c}\text { Reciprocating } \\
\text { Engine }\end{array}$} \\
\hline $\begin{array}{c}2800 \\
\text { hr/day }\end{array}$ & $\begin{array}{c}8000 \\
\text { hr/day }\end{array}$ & $\begin{array}{c}2800 \\
\text { hr/day }\end{array}$ & $\begin{array}{c}8000 \\
\text { hr/day }\end{array}$ \\
$\begin{array}{c}\text { Natural Gas Consumption } \\
\text { (million m } / \text { year) }\end{array}$ & 6.64 & 18.4 & 1.62 & 4.50 \\
$\begin{array}{c}\text { Electricity Cost per Year } \\
\text { (million USD / year) }\end{array}$ & 2.16 & 5.99 & 0.53 & 1.46 \\
$\begin{array}{c}\text { Excess Electricity Profit } \\
\text { (million USD / year) }\end{array}$ & 1.44 & 2.55 & 0.53 & 0.94 \\
$\begin{array}{c}\text { O\&M Cost per year } \\
\text { (million USD / year) }\end{array}$ & 0.127 & 0.36 & 0.14 & 0.34 \\
$\begin{array}{c}\text { Per Unit Electricity Cost } \\
\text { (USD per kWh) }\end{array}$ & 0.14 & 0.14 & 0.059 & 0.059 \\
$\quad \begin{array}{c}\text { Net Profit } \\
\text { (million USD / year) } \\
\text { Installation Cost } \\
\text { (million USD) }\end{array}$ & -0.128 & -0.36 & 0.164 & -0.60 \\
$\quad \begin{array}{c}\text { Payback Period } \\
\text { (Years) }\end{array}$ & ----- & ---- & 2.08 & ----- \\
\hline
\end{tabular}

For the CHP cases, the cost analysis was based on the difference between the total cost and the profit obtained by the sale of excess electricity. The price of natural gas in Turkey, taken from the Turkish Statistical Institute, was $0.326 \mathrm{USD} / \mathrm{m}^{3}$ [41]. The excess electricity price is fixed by the Energy Market Regulatory Authority of the Republic of Turkey (EMRA). Under the Renewable Energy Resource Support Mechanism (RER), the selling price or tariff scheme is set by EMRA under its own regulation. According to these legislations, a company or institution can sell electricity for 10 years and, the excess electricity was sold at 0.133 USD per $\mathrm{kWh}$ for this study. This procedure was implemented for all the cases in order to analyze the cost scenario to estimate the better solution for the Institute. Table 8 displays the results for the gas turbine and reciprocating engine-based combined heat and power systems.

\section{Result and Discussion}

The techno-economic and environmental analysis is a clear representation of the benefits of the combined heat and power system for achieving a sustainable decentralized network and the support by the government in term of policies can lead towards the rapid development of an energy-efficient network in Turkey.

The environmental analysis represents a reduction of $8 \%$ in $\mathrm{CO}_{2}$ emission for the gas turbine case and $77 \%$ for reciprocating engine case in reference to the grid. Moreover, the reciprocating engine provides nearly $74 \% \mathrm{CO}_{2}$ reduction in comparison with the gas turbine and making it the best optimal system for achieving an environmental target.

The economic analysis is based on two indicators, per unit cost and total profit or expenditure by each system. The cost per $\mathrm{kWh}$ for the grid, gas turbine, and reciprocating engine 
case was $0.067 \mathrm{USD} / \mathrm{kWh}, 0.14 \mathrm{USD} / \mathrm{kWh}$ and 0.059 USD/kWh respectively. Moreover, for the annual electricity consumption, the total expenditure for the existing system was 0.81 million USD, while for the gas turbine, the total cost for the first case comes out to be 0.85 million USD and for the second case, 2.38 million USD. However, the reciprocating engine first case scenario provides a positive cash flow of 0.164 million USD per year, while the second scenario did not show any profit. The reason for this unexpected outcome is the high operation and maintenance cost and the fuel purchase cost in Turkey associated with gas turbine and reciprocating engine and no specific per unit sale price for CHP according to the technology.

It has been observed that the term CHP does not seem appealing in Turkey. It is only understandable by those who can see the bottom line of the energy analysis from the energy efficiency point of view. The appeal of CHP is less attractive than other techniques but the benefits are more important for achieving energy security in a practical manner. In order to increase the strength of the Turkey ESCO market, current models need to be revised. CHP can replace the existing conventional heating and cooling system by making them energy efficient, cost saving, low emissions and enhanced electricity stability networks using local resources and biomass or geothermal resources integration. The policy must address a clear role of CHP and its future development to give a direction in order to sort out the problems for basic infrastructure development. The following areas must be taken into consideration while developing an action plan for CHP:

- Concise, Predictable Regulatory Framework and Tariff scheme.

- Heating, Cooling, and Electricity Consumption Monitoring and Recordkeeping.

- Financial Incentives

- 3rd Party Financing.

- Ease of market Integration.

- Decentralized Energy Networks for achieving security and to reduce network losses.

- Investment subsidies based on projects,

- Feed-in tariff schemes,

- Green certificate schemes,

- Third party financing,

- Policy favouring use of other fuel sources.

Having shown the necessary changes required in the energy policy, rapid growth can only be achieved if one favors a technology that is sustainable, cheap and environmentally friendly.

\section{Conclusions}

The aim of this study was to carry out a detailed economic, environmental and policy analysis of a combined cycle system in Turkey in the light of the study carried out for the Izmir Institute of Technology. The Turkish energy policy is focused on renewable energy, especially wind and solar energy, without much attention to CHP on medium and small scale and energy efficiency. In contrast, the integration of the combined cycle systems with renewable energy systems has allowed many countries to achieve their goal of reducing energy imports to nearly zero levels.

The Turkish renewable energy market is growing but the role of the combined cycle is not sufficient. Industrial-scale activities make most of the proportion of the combined cycle, which accounts for a small percentage within the total energy demand. Turkey has great potential to save energy from heating and cooling especially in residential and commercial areas. Significant improvements in policies can bring revolutionary changes in terms of energy-saving, meanwhile developing the local combined cycle market by motivating investors, inventors, stakeholders, and government policymakers.

The result of the study clearly shows that the implementation of the combined heat and power systems can improve the heating, cooling and electricity infrastructure in Turkey. The environmental analysis verifies that the reciprocating engine based CHP system will generate $77 \%$ fewer emissions and the gas turbine $8 \%$ when compared with grid-based emissions. Also, the economic analysis in terms of per-unit cost and overall savings in case of reciprocating engine is more suitable than any other scenario.

Even though there are currently no subsidies or incentives to promote CHP and DHC systems in Turkey, the reciprocating engine showed a promising income for the investors and also for the institute in terms of efficiency, cost-benefit analysis, environmental conservation and sustainability. Moreover, integrated and intelligent systems are the frontier of the $5^{\text {th }}$ generation energy systems, where issues such as stability, fluctuations, reliability in the renewable energy network is eliminated and modernized. Thus each technology plays its part in the future energy network and serves as a role model for other countries.

In the future, this study can be extended for the integrated CHP with other renewable energy systems, as with the increase in the demand of utilities; the hybrid system can provide the best solution.

\section{Acknowledgment}

This work was supported by The Scientific and Research Council of Turkey (TUBITAK). The first author is the recipient of a TUBITAK fellowship (16698286-215.0199618). 


\section{References}

[1] https://www.iea.org/publications/freepublications/public ation/WEO2015SpecialReportonEnergyandClimateCha nge.pdf

[2] Nami, H., Mahmoudi, S., \& Nemati, A. 2017, "Exergy, economic and environmental impact assessment and optimization of a novel cogeneration system including a gas turbine, a supercritical $\mathrm{CO} 2$ and an organic Rankine cycle (GT-HRSG/SCO2)", Applied Thermal Engineering, 110, 1315-1330.

[3] Gopalakrishnan, H., \& Kosanovic, D. 2014, "Economic optimization of combined cycle district heating systems", Sustainable Energy Technologies and Assessments, 7, 91100.

[4] Mondol, J. D., \& Carr, C. 2017, "Techno-economic assessments of advanced Combined Cycle Gas Turbine (CCGT) technology for the new electricity market in the United Arab Emirates". Sustainable Energy Technologies and Assessments, 19, 160-172.

[5] Balli, O., Aras, H., \& Hepbasli, A. 2007, "Exergetic performance evaluation of a combined heat and power (CHP) system in Turkey", International Journal of Energy Research, 31(9), 849-866.

[6] Celador, A. C., Erkoreka, A., Escudero, K. M., \& Sala, J. 2011, "Feasibility of small-scale gas engine-based residential cogeneration in Spain”, Energy Policy, 39(6), 3813-3821.

[7] Nemati, A., Nami, H., Ranjbar, F., \& Yari, M. 2017, “A comparative thermodynamic analysis of ORC and Kalina cycles for waste heat recovery: a case study for CGAM cogeneration system". Case Studies in Thermal Engineering, 9, 1-13.

[8] Giarola, S., Forte, O., Lanzini, A., Gandiglio, M., Santarelli, M., \& Hawkes, A. 2018, "Techno-economic assessment of biogas-fed solid oxide fuel cell combined heat and power system at industrial scale", Applied Energy, 211, 689-704.

[9] Karlsson, J., Brunzell, L., \& Venkatesh, G. 2018, "Material-flow analysis, energy analysis, and partial environmental-LCA of a district-heating combined heat and power plant in Sweden", Energy, 144, 31-40.

[10] Havukainen, J., Nguyen, M. T., Väisänen, S., \& Horttanainen, M. 2018, "Life cycle assessment of smallscale combined heat and power plant: Environmental impacts of different forest biofuels and replacing district heat produced from natural gas", Journal of Cleaner Production, 172, 837-846.

[11] Szega, M., \& Żymełka, P. 2018, "Thermodynamic and Economic Analysis of the Production of Electricity, Heat, and Cold in the Combined Heat and Power Unit With the
Absorption Chillers", Journal of Energy Resources Technology, 140(5), 052002.

[12] Keynia, F. 2018, “ An optimal design to provide combined cooling, heating, and power of residential buildings", International Journal of Modelling and Simulation, 1-16.

[13] Tataraki, K. G., Kavvadias, K. C., \& Maroulis, Z. B. 2018, "A systematic approach to evaluate the economic viability of Combined Cooling Heating and Power systems over conventional technologies", Energy, 148, 283-295.

[14] http://www.inforse.org/europe/eu_cogen-di.htm

[15] https://ec.europa.eu/eu2020/pdf/eu2020_en.pdf

[16] https://www.cogeneurope.eu/images/profiles/COGEN \%20Europe\%20ECR\%20-20Germany\%20Preview.pdf

[17] https://www.climateinvestmentfunds.org/sites/cif_enc/ files/CTF_Presentation_2_Turkey_update.pdf

[18] https://www.oe-eb.at/dam/jcr:c4a98592-294b-49db8536-4104286d2ce3/OeEB-Study-Energy-EfficiencyFinance-Serbia.pdf

[19] http://www.stadinilmasto.fi/hyvia-esimerkkeja/viikinymparistotalo-suomen-vahiten-energiaa-kuluttavatoimistorakennus/.

[20] https://www.bmu.de/fileadmin/bmuimport/files/englis h/pdf/application/pdf/klimapaket_aug2007_en.pdf

[21] https://policy.asiapacificenergy.org/node/3168

[22] Centre for Climate and Energy Solutions, 2011, "Climate Tech Book: Cogeneration/Combined Heat and Power (CHP), Center for Climate and Energy Solutions.

[23] http://www.bbc.com/weather/

[24] https://www.solarturbines.com/en_US/products/power -generation-packages/centaur-40.html

[25] https://www.clarke-energy.com/wpcontent/uploads/ETS_E_T4_update13_rz.pdf

[26] Duzen, M. 2014, "Natural Gas Measurement", Flow Control Magazine.

[27] Flagan, Richard C. and Seinfeld, John H. 1988, "Fundamentals of Air Pollution Engineering", PrenticeHall, Inc., Englewood CLiffs, New Jersey.

[28] McAllister, S., Chen, J.-Y., \& Fernandez-Pello, A. C. 2011, "Fundamentals of Combustion Processes", New York, NY: Springer New York.

[29] Ganapathy, V. 1991, "Waste heat boiler deskbook", Fairmont Press, University of Michigan.

[30] Ganapathy, V. 1997, "Efficiently generate steam from cogeneration plants", Chemical Engineering, 104(5).

[31] Ganapathy, V. 2001, "Options for Improving the Efficiency of Heat Recovery Steam Generators", EE Online. 
[32] https://www.pbs.cz/en/our-

business/powergineering/turbines/steam-condenserturbines

[33] https://new.siemens.com/global/en/products/energy/pow er-generation/steam-turbines.html

[34] https://www.epa.gov/sites/production/files/201507/documents/emission factors 2014.pdf

[35] https://www.epa.gov/sites/production/files/201507/documents/emission-factors 2014.pdf

[36] Brander, M., Sood, A., Wylie, C., Haughton, A., \& Lovell, J. 2011, "Technical Paper | Electricity-specific emission factors for grid electricity", ecometrica, August 2011.

[37] https://www.garantiinvestorrelations.com/en/images/pdf 12015-Electricity-Market-Report.pdf

[38] https://data.worldbank.org/indicator/EG.ELC.LOSS.ZS

[39] http://www1 eere. energy. gov/industry/pdfs/webcast_2009-0514_chp_in_facilities. pdfml.

[40] https://understandingchp.com/chp-applications-guide/68-rules-of-thumb-for-chp-engineering-and-installationcosts/

[41] http://www.turkstat.gov.tr/PreHaberBultenleri.do?id=21 $\underline{586}$ 